Vol. 5, No. 1, Juni 2020, pISSN 2527-2853, eISSN 2549-2985

\title{
Merumuskan Konsep Desain Interior
}

\section{Anggra Ayu Rucitra}

Departemen Desain Interior, Institut Teknologi Sepuluh Nopember

anggra@interior.its.ac.id

\begin{abstract}
ABSTRAK
Konsep desain, adalah ruh dalam mendesain interior. Terkadang mahasiswa dan desainer kesulitan dalam menentukan bagaimana konsep desain yang tepat untuk perancangan interiornya. Studi ini akan merumuskan tahapan bagaimana mendesain interior. Faktor-faktor apa sajakah yang diperhatikan, studi apakah yang harus dilakukan, dan bagaimana merangkumnya menjadi konsep desain. Tulisan ini adalah panduan bagi mahasiswa atau desainer dalam menyusun konsep desain. Metode yang digunakan adalah literature review dan depth interview terhadap para profesional desainer interior.
\end{abstract}

Kata kunci: desain interior; metode desain interior; konsep desain interior

\section{ABSTRACT}

The concept of design is the spirit in designing interiors. Sometimes students and designers have difficulty determining how to construct the right design for interior. This study will formulate the stages of how to design interiors. What factors are taken, studies to be carried out, and how to summarize them into design concepts. This paper is a guide for students or designers in designing interior concepts. The method used is a literature review and in-depth interviews with professional interior designers.

Keyword: interior design; interior design methods; interior design concepts

\section{PENDAHULUAN}

Penyusunan konsep interior adalah proses yang harus dilakukan oleh desainer interior dalam menghasilkan sebuah karya desain interior. Namun, bagaimana cara menyusun konsep desain interior yang sesuai dengan kebutuhan pengguna, memenuhi persyaratan teknis, mengikuti perkembangan trend, mudah diaplikasikan, efisien dan tepat guna, belum banyak literature yang membantu desainer dalam menyusun konsep. Studi ini dilatarbelakangi oleh masih terdapat kesalahan mahasiswa dan desainer dalam menyusun konsep desain interior. Kebanyakan konsep disusun berdasarkan keinginan desainer dan tidak berlatarbelakang kebutuhan pengguna dan kesesuaian dengan objek desain.

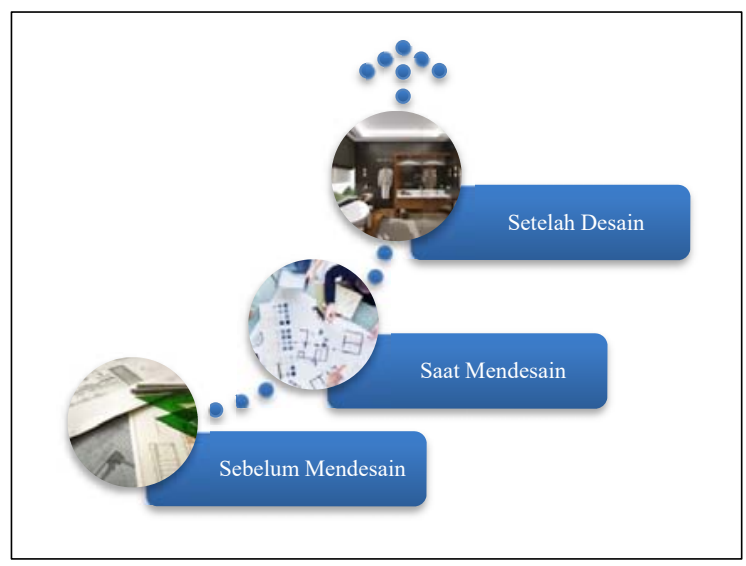

Gambar 1. Proses Design

Sumber: Dokumentasi Penulis (2020) 
Menurut studi yang dilakukan oleh Millburn et all (2003), "Research is incorporated at three stages of the design process: before design; during design; and after design. Before design, there appear to be two categories of research: indirect (which includes intrinsic research, library research, and review of precedents and case studies); and direct (which includes site inventory and analysis). During design, research seems to have two key roles: influencing the concept generation process and the application of the concept on the site. Five models emerged for using research during design: artistic, intuitive, adaptive, analytical, and systematic. Finally, after design research has two roles: evaluation of design, and justification of design". Secara umum tahapan studi oleh Millburn et all, dilakukan dalam 3 tahap yaitu sebelum, saat, dan setelah desain dilaksanakan. Pada proses pendidikan desain interior tahapan yang dilaksanakan adalah hingga pada saat mendesain. Namun, pada pelaksanaan proyek secara profesional perlu dilengkapi hingga evaluasi desain. Studi kali ini, berusaha untuk lebih mendetailkan tahapan tahapan tersebut. Terutama yang bisa diaplikasikan oleh mahasiswa dalam menyusun konsep desain.

\section{METODE PENELITIAN}

Metode yang digunakan dalam penelitian ini sebagai berikut:

\section{A. Data Literatur}

Tahap awal dalam merumuskan konsep desain dalam riset ini adalah mengumpulkan data literatur dan referensi teori yang mendukung pendetailan perancangan konsep desain. Berikut referensi teori serta studi literature yang digunakan pada riset:

1) Desain Interior

Desain adalah proses untuk mempermudah kehidupan manusia secara berkelanjutan. Desain interior adalah rangkaian proses merencanakan sebuah fasilitas ruang yang sesuai dengan kebutuhan penggunanya secara fisik dan psikologis. Desain interior bukan hanya merencanakan fasilitas dalam ruang, tetapi juga memberi nuansa ruang tersebut yang berdampak positif bagi penggunanya. Untuk membuat sebuah desain, diperlukan kreatifitas yang harus berdasar dengan kebutuhan pengguna dan kondisi eksisting. Maka faktor yang perlu diperhatikan saat awal mendesain interior adalah 3 hal yaitu:

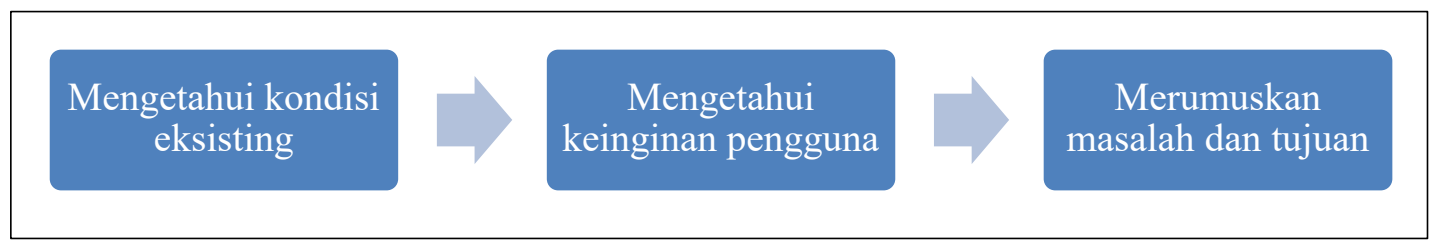

Gambar 2. Faktor Awal

Sumber: Dokumentasi Penulis (2020)

Untuk mengetahui kondisi eksisting, kebutuhan pengguna dan merumuskan masalah dan tujuan perlu dilakukan studi awal. Menurut Milburn et. all., proses ini dilaksanakan sebelum mendesain. Studi ini biasanya dilaksanakan secara langsung dilapangan berupa pengukuran dan pengecekan kondisi lapangan. Wawancara kepada pengguna dan stakeholder. Tahapan studi awal terdapat dua tahapan yaitu studi pengguna dan studi eksisting.

Sesuai dengan Millburn et. all., data-data tersebut adalah data yang harus diketahui sebelum mendesain. Studi pengguna adalah studi yang dilakukan kepada pengguna fasilitas, baik pemilik, pengunjung maupun pengelola. Eksisting adalah studi mengenai kondisi bangunan dan citra perusahaan atau profil perusahaan. 


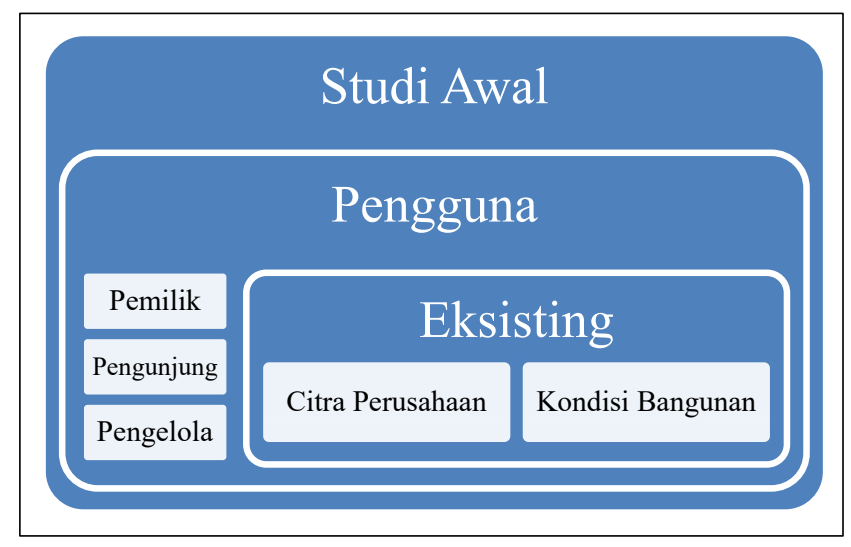

Gambar 3. Studi Awal

Sumber: Dokumentasi Penulis (2020)

\section{2) Studi Eksisting}

Studi awal adalah riset awal yang perlu dilakukan oleh desainer, untuk mengetahui pengguna dan eksisting. Seperti yang disampaikan pada gambar diatas maka pengguna perlu diketahui kebutuhannya termasuk pemilik, penggunanya dan pengelolanya. Dalam studi eksisting juga perlu diketahui data dasar bangunan, termasuk luasan, struktur, kondisi bangunan, dan lokasi. Citra perusahaan termasuk dalam studi eksisiting, karena citra perusahaan nantinya akan mencirikan desain.

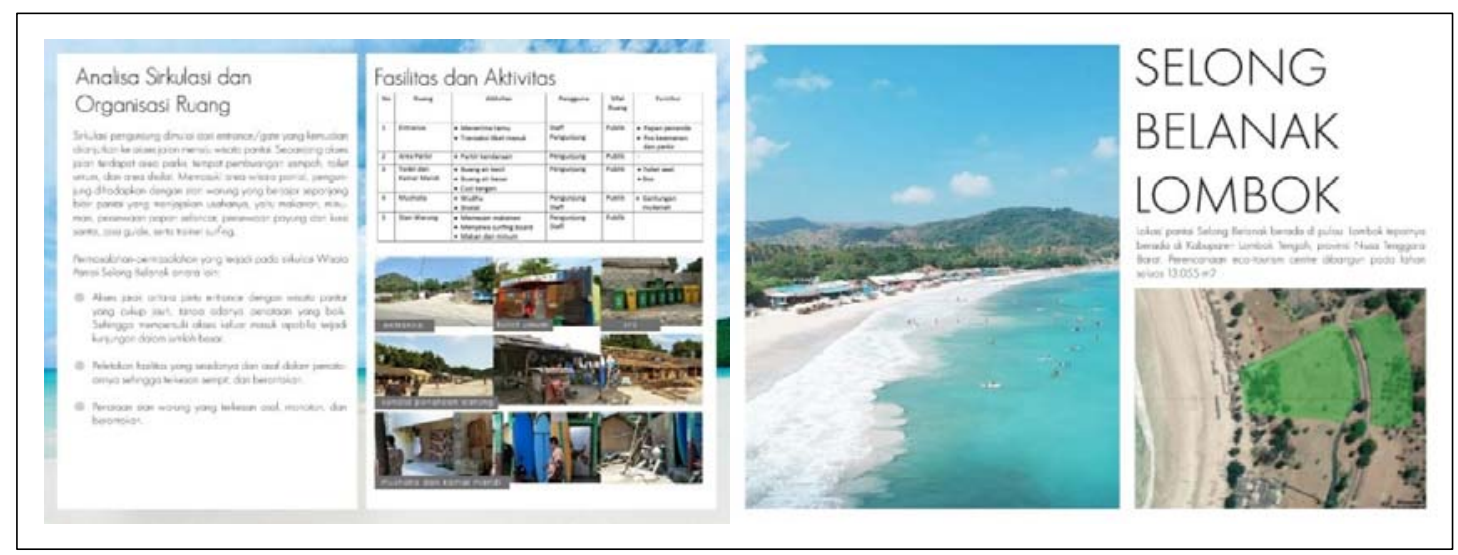

Gambar 4. Studi Eksisting

Sumber: Dokumentasi Penulis (2020)

Bagaimana jika yang akan didesain tidak memiliki citra perusahaan, hanya individu? Maka yang perlu distudi adalah individu tersebut sebagai pengguna. Dari buku The Fundamental of Interior Design, diketahui studi awal bertujuan untuk memahami project, memahami area dan memahami struktur bangunan. Cara menuliskan studi dalam buku konsep desain interior adalah analisis deskriptif yang merujuk pada sumber. Serta dapat menambahkan image board yang diperoleh dari sumber atau sketsa desain pengguna. Berikut adalah hal-hal yang perlu dilakukan dalam studi eksiting: 
1. Studi Corporate Image

2. Studi layout bangunan eksisting (denah eksisting)

3. Studi kondisi eksiting (foto eksisting)
4. Studi sirkulasi

5. Studi struktur bangunan

6. Studi arah dan lokasi bangunan

\section{3) Studi Pengguna}

Data studi pengguna adalah hal utama yang harus dilakukan oleh desainer. Karena tujuan dari desain adalah mempermudah manusia. Oleh sebab itu, latar belakang sebuah desain adalah kebutuhan penggunanya. Tahapan studi pengguna:

a. Identifikasi pengguna

Berikut adalah contoh tabel untuk mengidentifikasi pengguna

Tabel 1. Studi Pengguna

\begin{tabular}{|l|l|}
\hline $\begin{array}{l}\text { Judul } \\
\text { Perancangan }\end{array}$ & \\
\hline Nama Pemilik & $\begin{array}{l}\text { Hunian/kantor/bangunan } \\
\text { komersial/fasilitas public/lainnya, } \\
\text { jelaskan }\end{array}$ \\
\hline Fungsi Objek & \\
\hline Jumlah pengguna \\
\hline $\begin{array}{l}\text { Keinginan khusus } \\
\text { pemilik }\end{array}$
\end{tabular}

Sumber: Dokumentasi Penulis (2020)

Selain itu diperlukan data lain yang harus diketahui, baik dilakukan dengan wawancara maupun dengan kuesioner. Data yang harus diketahui dari pengguna adalah:

1. Segmentasi (kelas ekonomi)

2. Demografi (gender, usia, lokasi)

3. Preferensi terhadap objek yang akan di desain

Data tersebut biasanya dibutuhkan untuk perencanaan yang bersifat fasilitas publik, komersial seperti toko maupun hunian.

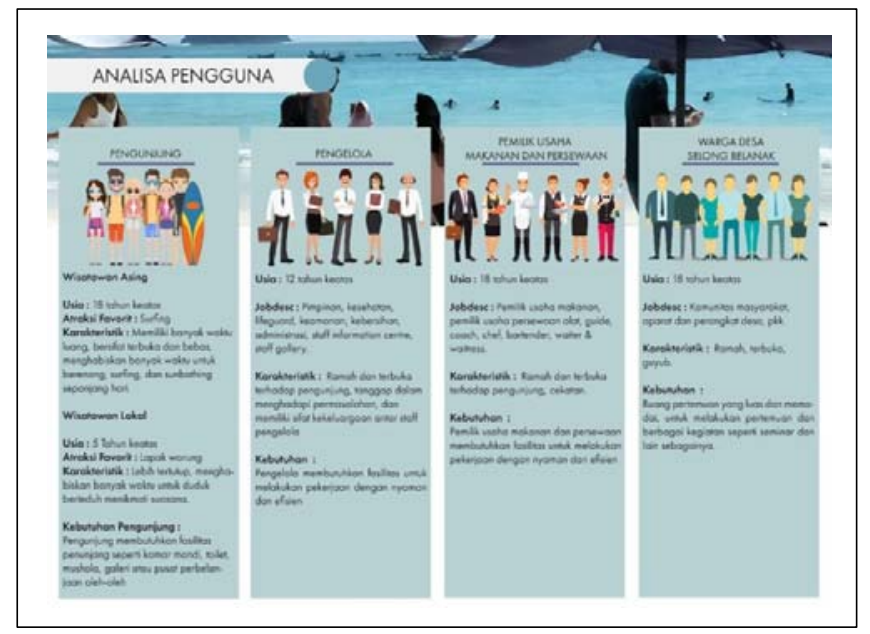

Gambar 5. Studi Pengguna

Sumber: Dokumentasi Penulis (2020) 
b. Studi Aktifitas Pengguna

Tahapan selanjutnya adalah melakukan riset tentang siapa saja penggunanya dan klasifikasi pengguna. Dalam tahap ini perlu diketahui siapa semua pengguna objek desain. Semisal pada hunian maka perlu diketahui siapa pemiliknya dan siapa saja penghuninya. Jika pada bangunan komersial maka perlu diketahui keinginan pemilik terhadap perusahaan, siapa target konsumennya, keinginan konsumennya dan bagaimana kebutuhan pengelola atau karyawannya. Semakin kompleks objeknya semakin banyak studi pengguna yang harus dilakukan. Sebagai contoh pada tabel berikut:

Tabel 2 Studi Aktivitas Pengguna

\begin{tabular}{|r|r|r|r|r|r|r|r|}
\hline Objek Desain : Bank AA Cabang ITS \\
\hline & \multicolumn{1}{|l|}{ Jenis Pengguna } \\
\hline & Nasabah & $\begin{array}{r}\text { Kepala } \\
\text { Cabang }\end{array}$ & Teller & CSO & Security & $\begin{array}{r}\text { Back } \\
\text { Office }\end{array}$ & $\begin{array}{r}\text { Kebersihan } \\
\text { outsource }\end{array}$ \\
\hline Jumlah & $\begin{array}{r}150 \text { orang/ } \\
\text { hari }\end{array}$ & 1 & 4 & 4 & 2 & 4 & 1 \\
\hline
\end{tabular}

Sumber: Dokumentasi Penulis (2020)

\section{4) Studi Aktivitas}

Studi aktivitas adalah kelanjutan dari studi pengguna, yang perlu dilakukan adalah mendata aktivitas masing masing pengguna. Sehingga diketahui kebutuhan ruang, furnitur dan dapat dihitung luasan dan fasilitas tambahan yang dibutuhkan. Berikut adalah contoh deskripisi aktivitas pada tabel aktivitas. Ini adalah studi aktivitas yang dilakukan pada sebuah Tourism Information Centre. Sebuah fasilitas public dengan luasan $1000 \mathrm{~m}^{2}$.

Tabel 3 Contoh Studi Aktivitas

\begin{tabular}{|c|c|c|c|c|c|c|c|c|c|c|c|c|c|}
\hline \multirow[b]{2}{*}{ No } & \multirow[b]{2}{*}{ Pengguna } & \multirow[b]{2}{*}{ Altivitas } & \multirow[b]{2}{*}{ Kebutuhan Ruang } & \multirow[b]{2}{*}{$\begin{array}{l}\text { Sifat } \\
\text { Ruang }\end{array}$} & \multirow[b]{2}{*}{$\begin{array}{l}\text { Kebutuhan } \\
\text { Furnitur }\end{array}$} & \multirow[b]{2}{*}{ Jumlah } & \multirow{2}{*}{$\begin{array}{c}\text { Dimensi } \\
(\mathrm{pxlxt})(\mathrm{cm})\end{array}$} & \multirow{2}{*}{$\begin{array}{c}\text { Luas } \\
\text { Furmitur } \\
\text { Satuan }\end{array}$} & \multicolumn{2}{|c|}{ Luas } & \multirow[b]{2}{*}{$\begin{array}{l}\text { Luas } \\
\text { Ruang }\end{array}$} & \multirow[b]{2}{*}{$\begin{array}{l}\text { Luas } \\
\text { Total }\end{array}$} & \multirow{2}{*}{$\begin{array}{l}\text { Luas } \\
\text { Total } \\
\left(\mathrm{m}^{2}\right)\end{array}$} \\
\hline & & & & & & & & & \begin{tabular}{|c|} 
Fumitur \\
5
\end{tabular} & \begin{tabular}{|c|} 
Sirkulasi \\
1
\end{tabular} & & & \\
\hline \multirow{4}{*}{1} & \multirow{4}{*}{ Kepala Pengelola } & Melakukan pekerjaan & \multirow{4}{*}{ Kantor kepala } & \multirow{4}{*}{ Privat } & Meja kerja & 1 & $200 \times 80 \times 75$ & 16000 & 16000 & 3200 & 19200 & \multirow{4}{*}{35904} & \multirow{4}{*}{3.5904} \\
\hline & & Menyimpan berkas & & & Kursi kerja & 1 & $60 \times 57 \times 111$ & 3420 & 3420 & 684 & 4104 & & \\
\hline & & & & & Kursi tamu & 1 & $50 \times 50 \times 95$ & 2500 & 2500 & 500 & 3000 & & \\
\hline & & & & & Storage & 1 & $200 \times 40 \times 200$ & 8000 & 8000 & 1600 & 9600 & & \\
\hline \multirow{3}{*}{2} & \multirow{3}{*}{$\begin{array}{l}\text { Wakil Kepala dan } \\
\text { Manager }\end{array}$} & \multirow{3}{*}{$\begin{array}{l}\text { Melakukan pekerjaan } \\
\text { Menyimpan berkas }\end{array}$} & \multirow{3}{*}{ Kantor pengelola } & \multirow{3}{*}{ Privat } & Meja kerja & 2 & $150 \times 80 \times 75$ & 12000 & 24000 & 4800 & 28800 & \multirow{3}{*}{46608} & \multirow{3}{*}{4.6608} \\
\hline & & & & & Kursi kerja & 2 & $60 \times 57 \times 111$ & 3420 & 6840 & 1368 & 8208 & & \\
\hline & & & & & Storage & 2 & $100 \times 40 \times 200$ & 4000 & 8000 & 1600 & 9600 & & \\
\hline \multirow{3}{*}{3} & \multirow{3}{*}{ Staff Manajemen } & \multirow{3}{*}{$\begin{array}{l}\text { Melakukan pekerjaan } \\
\text { Menyimpan berkas }\end{array}$} & & & Meja kerja & 5 & $120 \times 60 \times 75$ & 7200 & 36000 & 7200 & 43200 & & \\
\hline & & & Kantor manajemen & Privat & Kursi kerja & 5 & $50 \times 50 \times 95$ & 2500 & 12500 & 2500 & 15000 & 82200 & 8.22 \\
\hline & & & & & Storage & 5 & $100 \times 40 \times 200$ & 4000 & 20000 & 4000 & 24000 & & \\
\hline & & Melakukan pekerjaan & & & Meja kerja & 2 & $120 \times 60 \times 75$ & 7200 & 14400 & 2880 & 17280 & & \\
\hline 4 & Staff Administrasi & Menyimpan berkas & $\begin{array}{l}\text { Kantor } \\
\text { administrasi }\end{array}$ & Privat & Kursi kerja & 2 & $50 \times 50 \times 95$ & 2500 & 5000 & 1000 & 6000 & 32880 & 3.288 \\
\hline & & & & & Storage & 2 & $100 \times 40 \times 200$ & 4000 & 8000 & 1600 & 9600 & & \\
\hline & & Melakukan & & & Meja monitor cetv & 2 & $150 \times 80 \times 75$ & 12000 & 24000 & 4800 & 28800 & & \\
\hline 5 & Staff Keamanan & Menyimpan berkas & Kantor keamanan & Privat & Kursi kerja & 2 & $50 \times 50 \times 95$ & 2500 & 5000 & 1000 & 6000 & 44400 & 4.44 \\
\hline & & & & & Storage & 2 & $100 \times 40 \times 75$ & 4000 & 8000 & 1600 & 9600 & & \\
\hline 6 & & Melakukan & & & Kursi & 2 & $50 \times 50 \times 95$ & 2500 & 5000 & 1000 & 6000 & 15600 & \\
\hline 6 & Staff Lifeguard & Menyimpan peralatan & Lifeguard stand & Privat & Storage & 2 & $100 \times 40 \times 80$ & 4000 & 8000 & 1600 & 9600 & 15600 & 1.56 \\
\hline & & Perawatan & & & Meja perawat & 1 & $120 \times 60 \times 75$ & 7200 & 7200 & 1440 & 8640 & & \\
\hline & & Sterilisasi peralatan & & & Kursi & 1 & $50 \times 50 \times 95$ & 2500 & 2500 & 500 & 3000 & & \\
\hline 7 & Staff Kecelata & Istirahat & Klinik & Publik & Storage obat & 1 & $200 \times 40 \times 200$ & 8000 & 8000 & 1600 & 9600 & 38530 & 3850 \\
\hline 7 & Staff Kesehatan & & Kinix & Pullik & Storage linen & 1 & $200 \times 40 \times 200$ & 8000 & 8000 & 1600 & 9600 & 38920 & 3.852 \\
\hline & & & & & Wastafel steril & 1 & $80 \times 60 \times 80$ & 4800 & 4800 & 960 & 5760 & & \\
\hline & & & & & Tempat sampah & 1 & $40 \times 40 \times 50$ & 1600 & 1600 & 320 & 1920 & & \\
\hline 8 & Pengunjung & \begin{tabular}{|l} 
Perawatan \\
Istirahant
\end{tabular} & Klinik & Publik & $\begin{array}{l}\text { Tempat tidur } \\
\text { Kursi }\end{array}$ & 2 & $\begin{array}{c}250 \times 100 \times 80 \\
50 \times 50 \times 95\end{array}$ & $\begin{array}{r}25000 \\
2500\end{array}$ & $\begin{array}{r}50000 \\
5000\end{array}$ & $\begin{array}{r}10000 \\
1000\end{array}$ & $\begin{array}{r}60000 \\
6000\end{array}$ & 66000 & 6.6 \\
\hline
\end{tabular}

Sumber: Dokumentasi Penulis (2020)

Dari studi aktivitas tersebut dapat diketahui jumlah luasan kebutuhan ruang, dan fasilitas apa saja yang dibutuhkan. Selain itu desainer juga perlu melakukan observasi langsung dilapangan/eksisting untuk mengetahui perilaku pengguna dalam ruang. Sebagai contoh, pada objek perancangan sebuah restaurant. Perlu diketahui jumlah pengunjung, rata-rata pengunjung 
datang berkelompok dengan jumlah berapa orang? Hal ini diperlukan untuk menata kebutuhan kursi. Berapa banyak kursi untuk berdua, bereempat, berenam dan seterusnya.

Perlu diketahui juga dari studi lapangan, rata rata pengguna menyukai duduk diarea mana? Selain mengobrol, makan, apa yang dilakukan pengunjung. Hal ini dilakukan untuk memenuhi kriteria kenyamanan bagi pengunjung. Demikian juga mendata kebutuhan pengelola atau karyawannya. Sehingga, desainer dapat mengatur pola ruang dan sirkulasi yang memenuhi kenyamanan pengguna. Buku dan pedoman dalam menyusun studi aktivitas adalah Time-saver Standard, Neufret Architect Data dan New Metric Handbook.

\section{5) Alur Sirkulasi Pengunjung}

Alur sirkulasi pengunjung adalah studi tambahan mengenai aktivitas pengguna sehingga kita dapat mengetahui arah sirkulasi pengunjung pada denah eksisting. Dari gambar alur sirkulasi diatas kita juga dapat membedakan zoning area, serta akses pengguna.

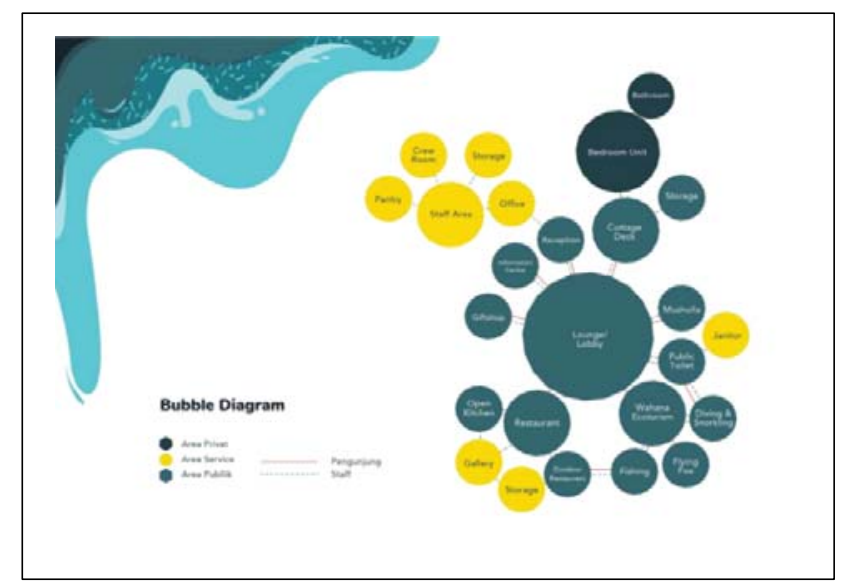

Gambar 6. Contoh Alur Sirkulasi Pengunjung Sumber: Dokumentasi Penulis (2020)

Tahapan selanjutnya dari skema material adalah penyusunan matriks hubungan ruang. Dari matrix hubungan ruang, sebelah kiri adalah list ruang dan sebelah kanan adalah matrix hubungan ruang yang menjadi dasar dalam menyusun layout ruang.

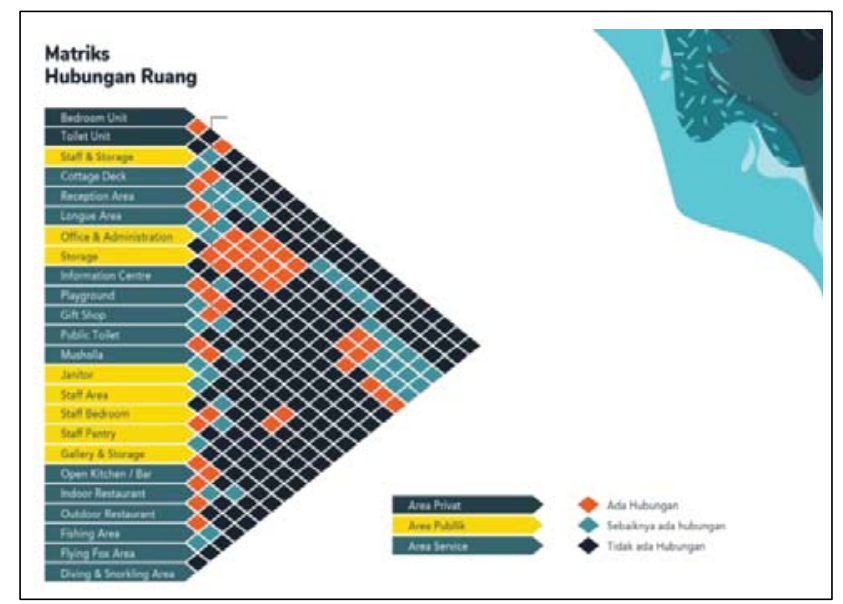

Gambar 7. Contoh Matrix Hubungan Ruang

Sumber: Dokumentasi Penulis (2020) 
6) Studi Literatur

Seorang desainer harus memiliki pengetahuan yang banyak tentang objek yang didesain. Hal itu bisa diperoleh dari studi tentang objek tersebut, baik secara langsung maupun melalui literature review. Studi studi pendahulu yang linear dengan objek anda dapat dijadikan referensi, terutama jurnal, prosiding, buku yang terbit 5 tahun terakhir. Sebagai contoh, jika objek perancangan anda adalah restaurant maka anda harus melakukan studi tentang apa itu restaurant? Jenis jenis restaurant? dan objek anda termasuk jenis restaurant yang mana? Anda boleh memasukan data tentang objek sebanyak mungkin pada literature namun harap diingat bahwa apa yang anda cantumkan harus sesuai dengan desain anda. Dan studi anda harus dapat dipertanggungjawabkan. Berikut adalah studi yang harus dilakukan dalam literature review terkait perancangan.

1. Fungsi objek (restaurant, kantor, hotel, dst

- Sejarah

- Jenis

2. Teori Karakter pengguna

3. Teori teori pendukung

- Ergonomic anthroprometri

- Sirkulasi

- Layout

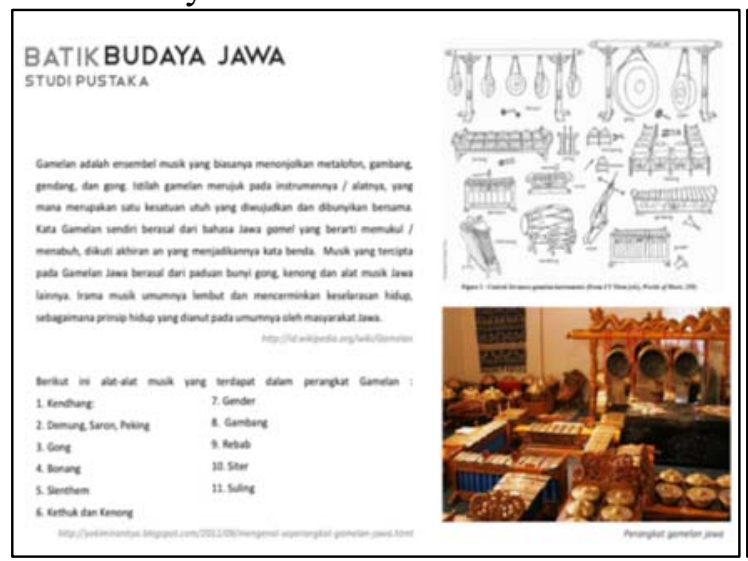

(a)
1. Konsep desain

- Sejarah

- Ciri

2. Warna

3. Material

4. Pencahayaan

5. Penghawaan

6. MEE

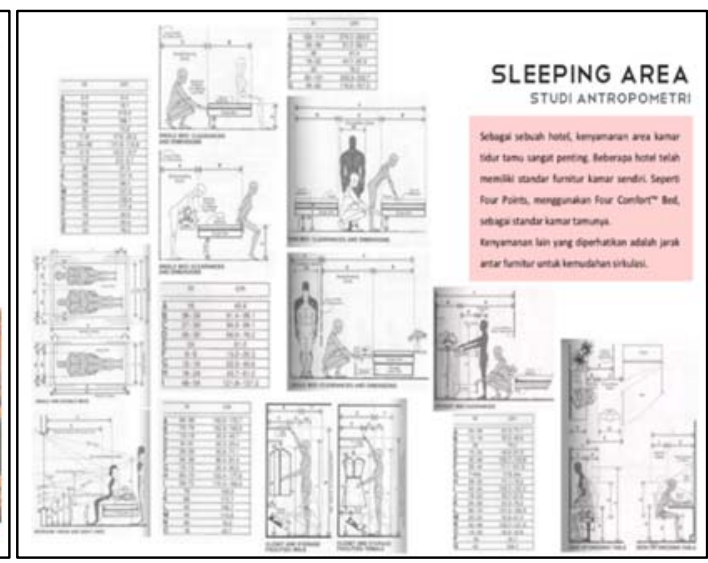

(b)

Gambar 8. Contoh Studi Literature (a) Batik Sebagai Budaya Jawa dan (b) Antropometri Sumber: Dokumentasi Penulis (2020)

Setelah melakukan studi diatas, perlu di beri keterangan disetiap studi literatur mengenai hasil studi. Kesimpulan maupun kutipan jenis apa yang nantinya bisa diaplikasikan di konsep anda.

7) Studi Pembanding

Ada 2 jenis studi pembanding, yaitu pembanding sebagai referensi desain dan pembanding sebagai kompetitor. Dimana studi pembanding dilakukan untuk memperkaya wawasan desainer terhadap objek desain. Pembanding bisa dilakukan pada objek desain yang memiliki karakter yang sama dengan objek. Misalnya, anda mendesain Perpustakaan maka anda harus mencari pembanding perpustakaan lain yang bisa anda jadikan referensi desain, sistem dan keunggulannya. 
Sedangkan kompetitor adalah pembanding setara yang cenderung menjadi pesaing, yang perlu distudi sistemnya, keunggulan yang bisa dimasukkan kedalam konsep desain dan kelemahan untuk dilengkapi dalam konsep desain. Sebagai contoh jika anda mendesain Perpustakaan Universitas A anda harus mencari pembanding terdekat, yaitu Perpustakaan Universitas B. Studi komparasi dapat dilakukan dengan tujuan mengambil keunggulan disetiap objek dan melengkapi kelemahan.

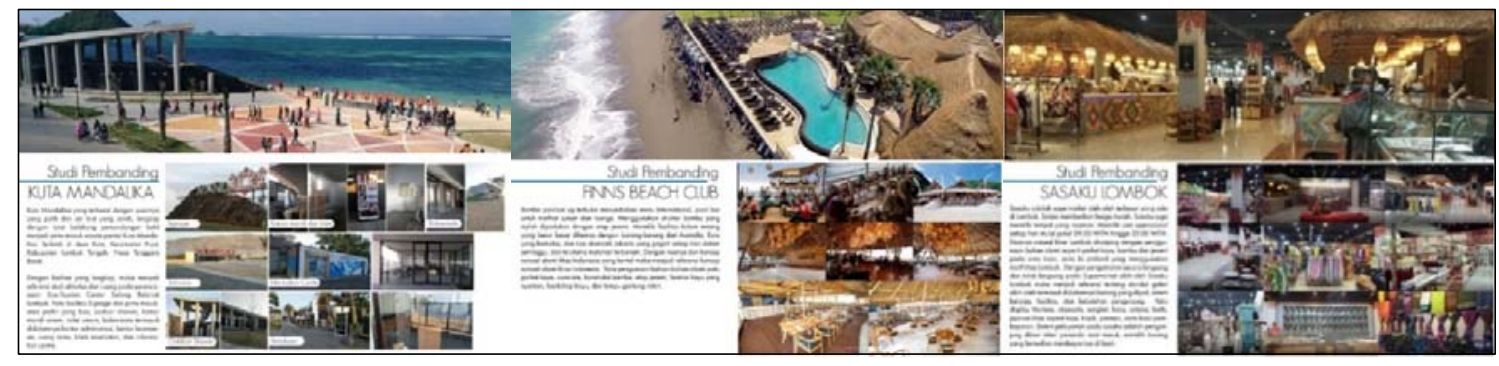

Gambar 9. Contoh Studi Pembanding Desain Sumber: Dokumentasi Penulis (2020)

\section{B. Pendetailan Tahapan}

Pendetailan tahapan untuk merancang suatu konsep desain interior dilakukan dengan memanfaatkan referensi teori yang diperoleh dari studi literarur. Selanjutnya dilakukan formulasi mengenai tahapan perancangan konsep desain interior. Dalam melakukan pendetailan tahapan perancangan konsep desain interior, proses didampingi dengan adanya studi eksisting untuk melihat bagaimana tren perumusan masalah pada perancangan desain interior yang dilakukan oleh mahasiswa maupun desainer pada umumnya sehingga akan terbentuk detail tahapan perumusan konsep desain interior yang bersifat fleksibel untuk seluruh kondisi.

\section{Tahapan Akhir}

Tahap ini merupakan tahap terakhir dari proses pendetailan tahapan perancangan konsep desain interior, sehingga terbentuk tahapan perancangan konsep desain yang bersifat fleksibel dan dapat diterapkan pada seluruh kondisi eksisting pada masyarakat.

\section{HASIL PENELITIAN DAN PEMBAHASAN}

Setelah melakukan studi mengenai kondisi eksisting dan keinginan pengguna, maka selanjutnya dilakukan perumusan masalah dan tujuan. Apabila telah dirumuskan permasalahan dan tujuan, kemudian menyusun konsep desain.

\section{A. Konsep dan Perancangan}

Berdasarkan studi eksisting dan studi literatur, dapat diketahui lebih detail rumusan masalah dan tujuan desain. Baik dari segi pengembangan fungsi eksisting maupun memenuhi kebutuhan pengguna dalam interior. 


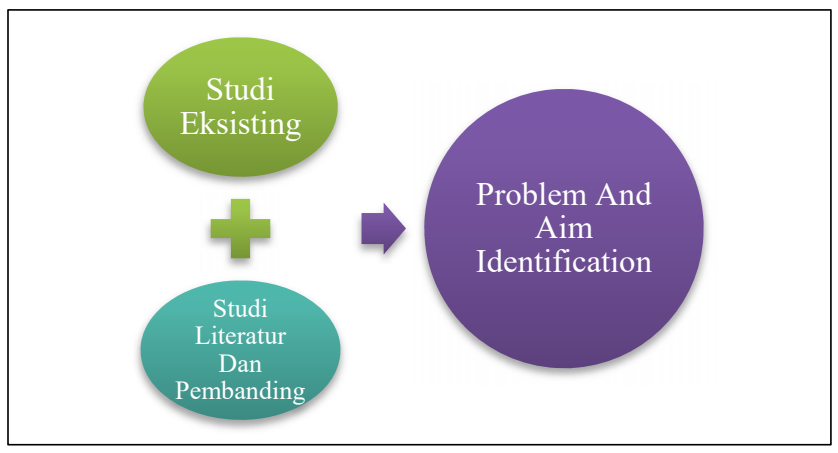

Gambar 10. Bagaimana Merumuskan Masalah dalam Interior Sumber: Dokumentasi Penulis (2020)

Untuk mengetahui rumusan masalah, setelah dilakukan studi eksisting perlu dilakukan studi literatur dan pembanding untuk semakin memahami tujuan dan masalah, kami mencoba mempermudah cara menentukan rumusan masalah secara umum dengan teori sebagai berikut, Teori rumusan masalah:

1. Representasi Corporate Image

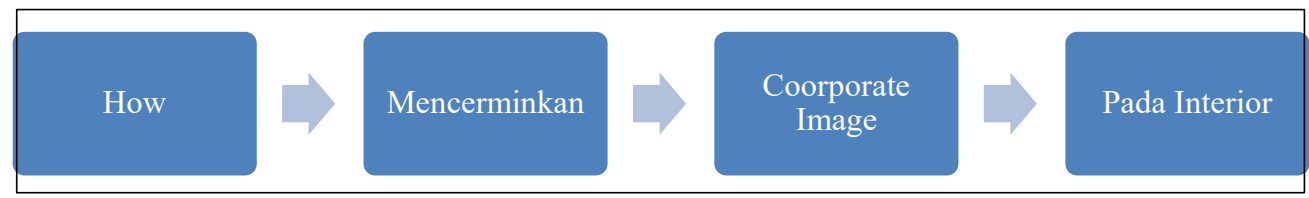

Gambar 11. Contoh Corporate Image

Sumber: Dokumentasi Penulis (2020)

Sebagai contoh, Bagaimana mencerminkan corporate image Restoran A dalam desain interiornya.

2. Memenuhi Kebutuhan Pengguna

Sebagai contoh, Bagaimana memenuhi kebutuhan pengguna yang adalah Ibu hamil pada desain interior klinik Maternity Yoga.

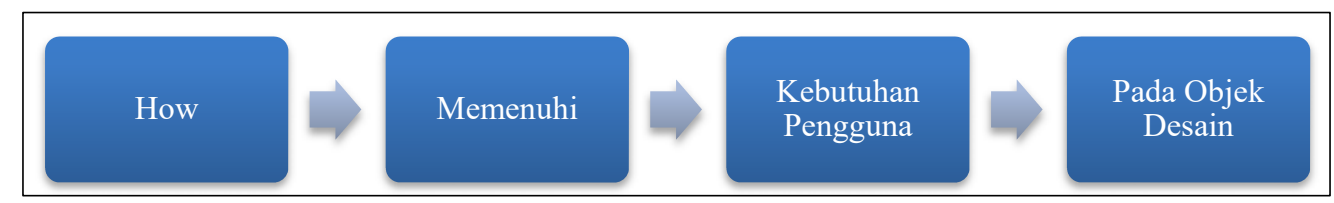

Gambar 12. Contoh Kebutuhan Pengguna Sumber: Dokumentasi Penulis (2020)

3. Mengaplikasikan ide baru

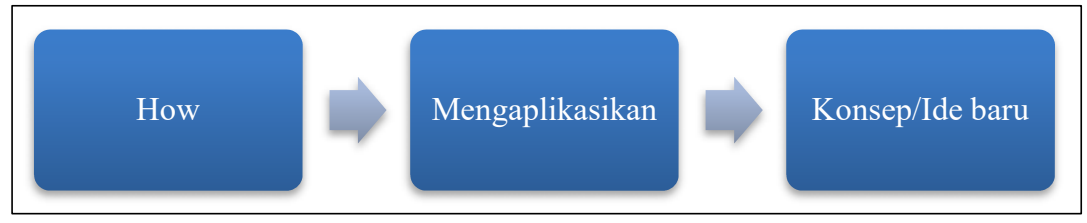

Gambar 13 Contoh Kebutuhan Pengguna Sumber: Dokumentasi Penulis (2020) 
Ide baru disini dapat di deskripsikan sebagai meningkatkan/mengoptimalkan fungsi objek desain menambahkan fungsi atau aktivitas baru. Sebagai contoh, bagaimana mengaplikasikan konsep informatif pada Perpustakaan XYZ. Teori tersebut adalah gambaran umum. Setiap kasus dan objek perancanaan memiliki tujuan dan masalah yang berbeda. Terdapat syarat dan ketentuan yang berlaku pada setiap objek perancangan. Secara umum dapat dicoba mengikuti teori tersebut, namun benar-benar harus disesuaikan dengan kebutuhan pengguna.

\section{B. Menyusun Konsep Desain}

Terdapat empat poin utama dalam penyusunan sebuah konsep desain yaitu: objek desain, pengguna, ide baru, dan coorporate image. Dari 4 hal tersebut, kemudian ditarik parameter atau keyword yang dapat mendeskripsikan lebih detail keyword tersebut. Dalam metode desain hal ini disebut mind mapping. Mindmap adalah versi kreatif fishbone chart atau tree method. Konsep desain berupa kesimpulan akhir yang merupakan simpulan atau solusi dari mindmap tersebut. Seperti yang digambarkan dalam chart berikut:

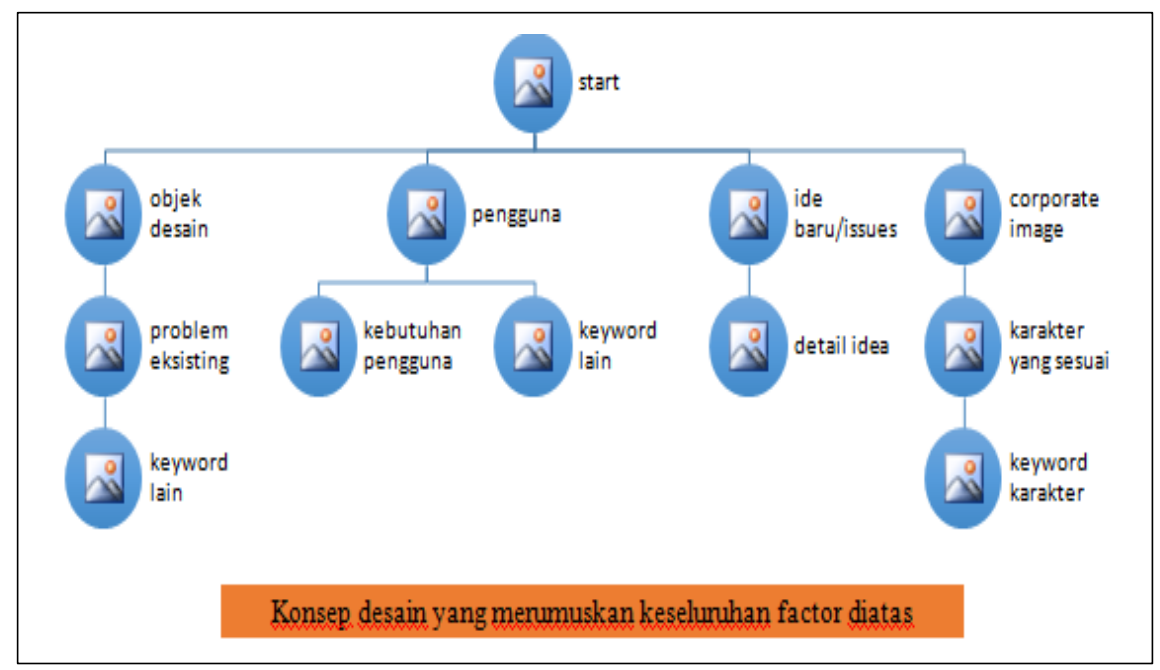

Gambar 14. Contoh Mindmap

Sumber: Dokumentasi Penulis (2020)

Konsep desain harus berangkat dari kebutuhan pengguna dan spesifikasi objek. Konsep desain ini yang nantinya akan diturunkan dalam konsep mikro desain interior. Jangan lupa bahwa konsep ini merupakan representasi tujuan dan dapat menyelesaikan masalah. Seperti dalam Jurnal Dimensi yang berjudul Dekorasi Gaya Jepang dalam Desain Interior Restaurant, oleh A. A. Rucitra diketahui bahwa kesesuaian konsep desain bergaya Jepang sesuai dengan kebutuhan restaurant interior masakan Jepang. Detail-detail furnitur dan asesoris merepresentasikan ciri restaurant yang mempertimbangkan pengguna dan bertujuan untuk menarik minat pengunjung. Demikian juga dari P. N. Asriningsih, A. A. Rucitra tentang Desain Interior Perpustakaan Grhatama yang berkonsep mandiri Rekreatif sebagai penunjang aktivitas pengguna, mandiri rekreatif adalah konsep yang ditawarkan sebagai solusi permasalahan desaon di perpustakaan tersebut. Berikut adalah contoh aplikasi tree method. 


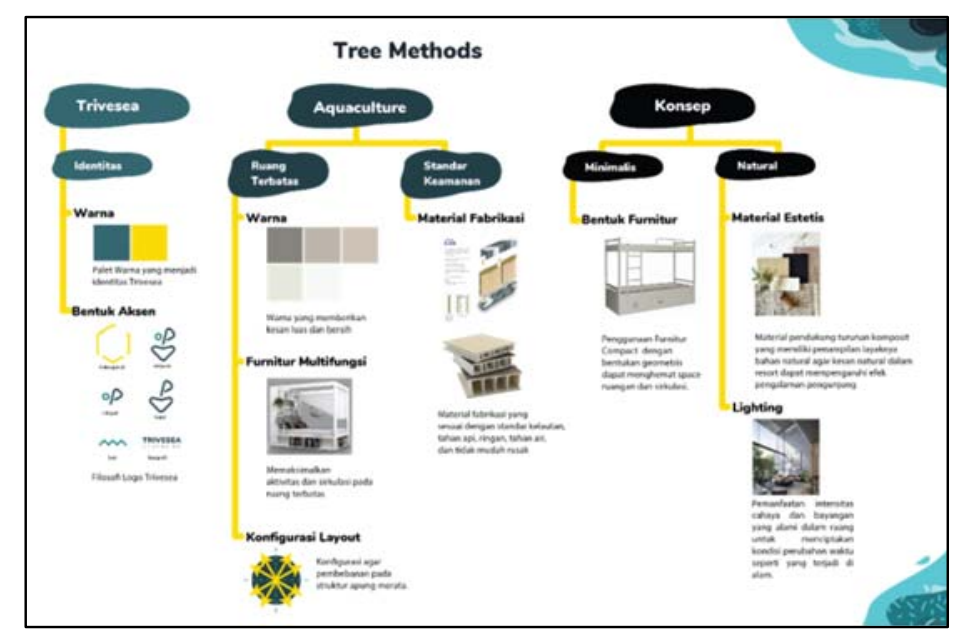

Gambar 15. Tree Method pada Desain Hotel di Aquaculture Sumber: Dokumentasi Penulis (2020)

Sekali lagi, dalam menyusun konsep desain harus disesuaikan dengan kebutuhan objek yang akan di desain. Dan sangat dimungkinkan bahwa setiap objek akan dimulai dari keyword yang berbeda. Namun secara umum dapat di rumuskan menggunakan obyek desain, pengguna, ide baru dan coorporate image.

1. Konsep Makro

Setelah ditemukan konsep secara umum, maka tahapan selanjutnya adalah mementukan konsep makro yang merujuk pada hasil konsep umum dari tree method dan ide baru yang ingin diaplikasikan. Berikut adalah contoh tahapan dalam konsep makro dalam interior.

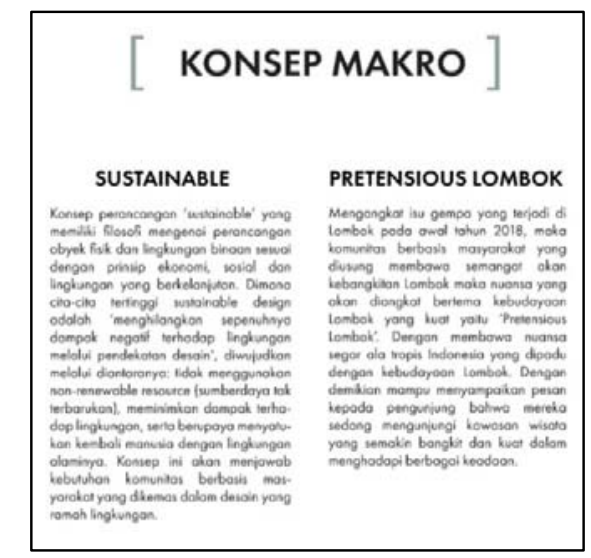

Gambar 15. Contoh Konsep Makro Desain Sumber: Dokumentasi Penulis (2020)

\section{Konsep Mikro}

Konsep mikro dapat dibagi menjadi konsep elemen pembentuk ruang. Elemen pembentuk ruang adalah dinding, lantai dan plafon. Namun disetiap konsep mikro juga terdapat konsep pendukung dinding, seperti warna, material, bentuk. Seperti contoh konsep dinding berikut: 


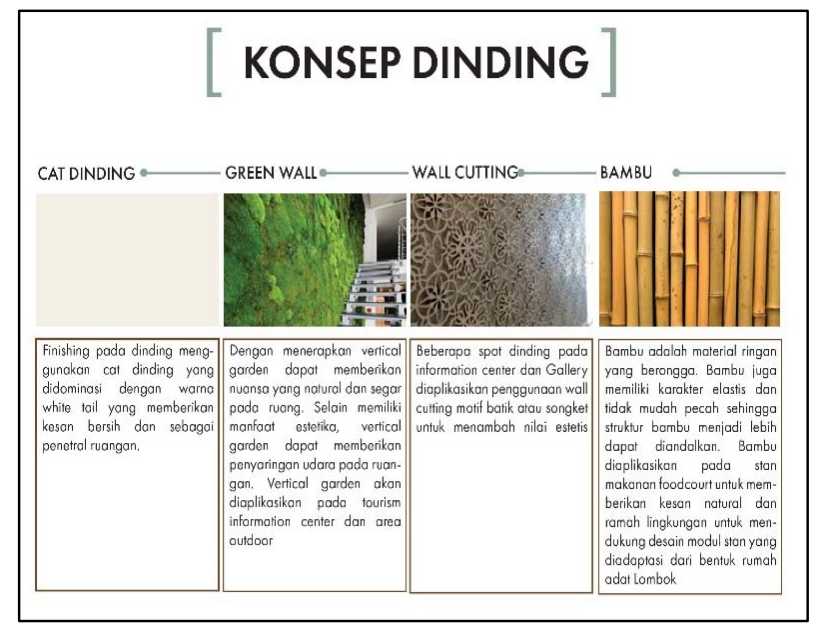

Gambar 17. Contoh Konsep Mikro Desain Sumber: Dokumentasi Penulis (2020)

Pada konsep mikro, juga diperbolehkan menyusun konsep pendukung lain yang dibutuhkan, seperti pencahayaan, mebel, penghawaan, keamanan, display system, EGD, dan lain sebagainya.

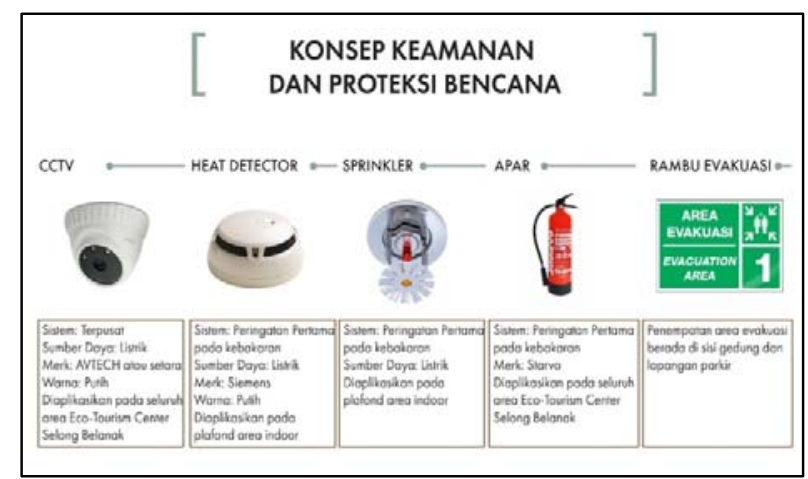

Gambar 18. Contoh Konsep Mikro Desain Penanggulangan Bencana Sumber: Dokumentasi Penulis (2020)

\section{Concept Board:}

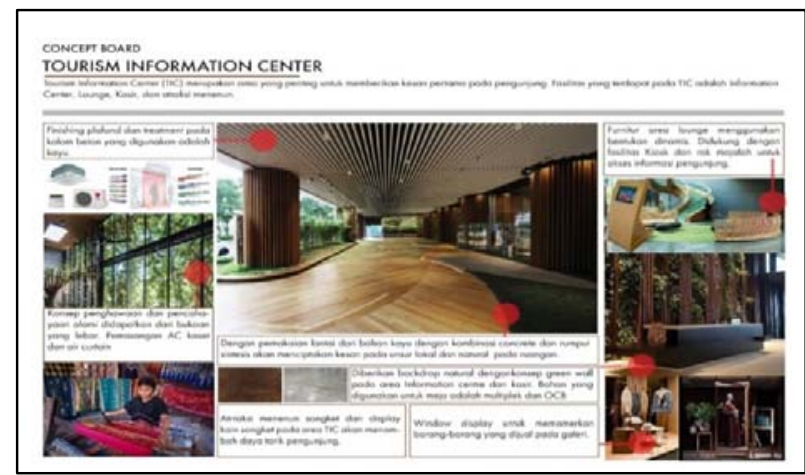

Gambar 19. Contoh Concept Board Per-ruang Sumber: Dokumentasi Penulis (2020) 
Selanjutnya mood board. Mood board dapat dibuat per ruang sesuai ruang terpilih. Konsep board atau mood board adalah media untuk mempermudah presentasi dalam desain interior.

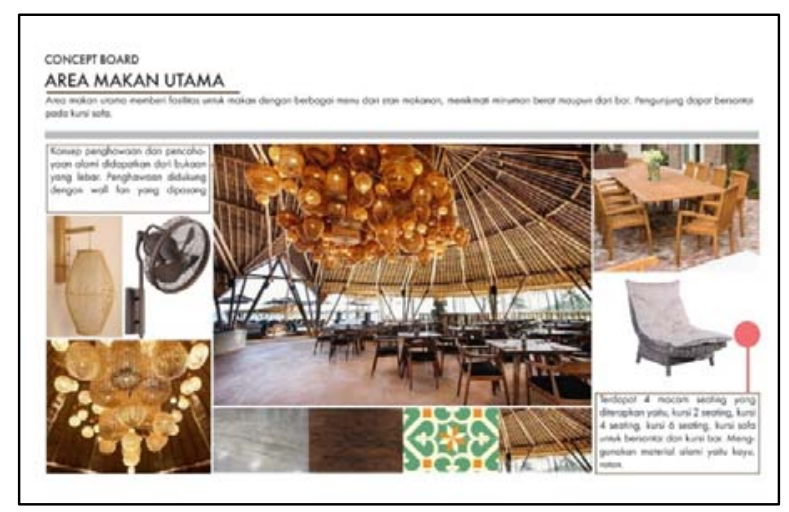

Gambar 20. Contoh Concept Board Per-ruang (Lanjutan) Sumber: Dokumentasi Penulis (2020)

\section{KESIMPULAN}

Berdasarkan dari tulisan ini dapat diketahui bahwa konsep harus sesuai dengan kebutuhan objek desain. Bukan sesuai dengan keinginan sang desainer. Desainer boleh merumuskan konsep desain merujuk pada tren namun harus dapat memfasilitasi kebutuhan penggunanya. Secara umum, konsep dapat ditarik melalui 4 hal utama yaitu, obyek desain, pengguna, ide baru dan corporate image. Dari empat hal tersebut, di tarik parameter atau keyword yang dapat mendeskripsikan lebih detail keyword tersebut. Dalam metode desain, hal ini disebut mindcmapping. Mindmap adalah versi kreatif fishbone chart atau tree method. Konsep desain berupa kesimpulan akhir yang merupakan simpulan atau solusi dari mindmap tersebut. Dalam menyusun konsep desain harus disesuaikan dengan kebutuhan objek yang akan di desain dan sangat dimungkinkan bahwa setiap objek akan dimulai dari keyword yang berbeda sesuai dengan kebutuhannya.

\section{DAFTAR PUSTAKA}

A. A. Rucitra, et. all. (2017). Dekorasi Gaya Jepang dalam Desain Interior Restoran. Jurnal Dimensi. Vol. 15 No. 1.

Ernst Neufert. (2019). Neufret Architect Data. United States: John Wiley and Sons Ltd.

Joseph D Ciara, Julius Panero, Martin Zelnik. Time-Saver Standards for Interior Design and Space Planning. New York: Mc Graw Hill.

Lee-Anne S. Milburna, Robert D. Brown. (2003). The Relationship Between Research and Design in Landscape Architecture. Landscape and Urban Planning. Volume 64, Issues 1-2, 15 June 2003, Pages 47-66.

New Metric Handbook.

P. N. Asriningsih, A. A. Rucitra. (2018). Desain Interior Perpustakaan Grhatama Pustaka yang Berkonsep Mandiri Rekreatif sebagai Penunjang Aktivitas Pengguna. Jurnal Sains dan Seni ITS. Vol. 17 No. 1.

Simon Dodsworth. (2009). The Fundamental of Interior Design. Switzerland: AVA Publishing SA. 
Anggra Ayu Rucitra

Merumuskan Konsep Desain Interior 